\title{
Classification System for Monitoring Historic Changes in Forest and Non-Forest Woody Vegetation-A Basis for Management
}

\author{
Jan Skaloš*, Zdeněk Keken, Helena Justová, Kateřina Křováková, Hana Chaurová \\ Faculty of Environmental Sciences, Czech University of Life Sciences Prague, \\ Prague, Czech Republic \\ Email: "skalos@knc.czu.cz, keken@knc.czu.cz, justova@knc.czu.cz, \\ krovakova@knc.czu.cz, chaurova@knc.czu.cz
}

Received October $12^{\text {th }}, 2013$; revised November $19^{\text {th }}$, 2013; accepted December $18^{\text {th }}$, 2013

\begin{abstract}
Copyright (C) 2014 Jan Skaloš et al. This is an open access article distributed under the Creative Commons Attribution License, which permits unrestricted use, distribution, and reproduction in any medium, provided the original work is properly cited. In accordance of the Creative Commons Attribution License all Copyrights @ 2014 are reserved for SCIRP and the owner of the intellectual property Jan Skaloš et al. All Copyright (C) 2014 are guarded by law and by SCIRP as a guardian.
\end{abstract}

Forest and non-forest vegetation fulfils many non-productive and productive functions. A good understanding of the trajectories and drivers of the woody vegetation change is necessary for the relevant management. Recently, the number of studies devoted to monitoring forest cover changes has increased. However, these works do not fully distinguish between different categories of forest and non-forest woody vegetation. The main aim of the study was to propose a classification system for monitoring historic changes of woody vegetation in the landscape. The period of the last 150 years was mapped through three time-lines (1842, 1953 and 2011). Data were obtained by interpreting historic maps (Stable Cadastral map of 1842) and historical (1953) and current orthophoto (2011) using ArcGIS tools. The classification was applied on the example of Sokolov region $\left(57 \mathrm{~km}^{2}\right)$ located in western Bohemia. The result of the research is a proposal for classifying woody vegetation stands into four categories based on the structural and localisation criteria: (1) Line adjacent woodlands, (2) Landscape woodlands, (3) Settlement woodlands, and (4) Compact woodlands. Information on the woody vegetation development using the proposed classification system is important for understanding the patterns, pressures, and driving forces that led to the formation of the present-day forest and non-forest woody vegetation in the landscape. The results can also be applied as a basis for future forest management practice as they can be used in other different fields, e.g. history, archaeology etc.

Keywords: Forest Development; Forest and Non-Forest Woody Vegetation; ArcGIS; Sokolov Region

\section{Introduction}

Apart from the productive roles, forest and non-forest woody vegetation has further non-production roles in the landscape (Ryszkowski \& Kedziora, 2007), such as ecological, landscapeforming, eco-stabilising, and aesthetics (McCollin, 2000). Nonforest woody vegetation plays an essential ecological role, especially in intensively used landscapes (Bulír \& Škorpík, 1987). Erosion control function refers to a positive effect on the intensity of water runoff, therefore reducing the risk of soil erosion (Pattanayak \& Mercer, 1997). It was recently confirmed that it is also important in mitigating climate change effects (Nair et al., 2009; Plieninger, 2011; Verchot et al., 2007; Manning et al., 2006). Small woodlands scattered in the landscape have become significant ecosystems that are important for biodiversity, both in agriculture (Manning et al., 2006) and in urban landscapes (Jim \& Chen, 2009). Woody vegetation features in the landscape bear witness to the historical utilisation of the landscape (Krčmářová, 2012), thus playing an important role in the so-called memory or heritage of the landscape (Schama, 1995).

Forests in most European countries experienced fundamental

\footnotetext{
${ }^{*}$ Corresponding author.
}

changes in the Holocene (Peterken, 1976; Hultberg, 2008; Ohlson \& Tryterud, 1999; Mercuri et al., 2011). The present condition of the Czech forest landscape is the result of the long interrelation between men and the natural and cultural landscape. An important milestone in the human attitude to the forest in the Czech lands was the adoption of Forest legislation in 1754, which laid the foundations for forest management. Although the Neolithic period is regarded as a breakpoint in man's growing impact on the Czech landscape and forests, the fundamental changes have occurred over the past five thousand years (Svoboda, 1952; Nožička, 1975; Löw \& Míchal, 2003; Sádlo et al., 2005; Ložek, 2007). The present methodology platform of historical geography (Semotanová, 2006) enables an extensive and complex analysis of transformations of the Earth's surface and its utilisation (changes in the so-called land cover/land use). There are recently published works that tackle transformations of forest cover (Brůna \& Křováková, 2006; Mathys et al., 2006; Kozak et al., 2008; Brandt et al., 2012; Plieninger et al., 2012a, b; Skaloš et al., 2012; Peterken, 1976; Ohlson \& Tryterud, 1999; Berg et al., 2008; Hultberg, 2008; Bollschweiler et al., 2008; Oosterbaan \& Pels, 2007). Research studies performed by environmental archaeologists or historians help to integrate con- 
siderations on the natural forest dynamics and cultural history of a country (Beneš et al., 2002; Cílová \& Woitsch, 2012). The identification and protection of natural or remnant patches of woody vegetation is an essential component of biodiversity conservation within these heavily transformed and managed agricultural landscapes. Remnant patches of vegetation may comprise important reservoirs of biodiversity and may contain biotic and structural legacies that are important for understanding and restoring native ecosystems (Lindenmayer \& Franklin, 2002). Indeed, the overall contribution of these areas to habitat provision, biodiversity conservation, and the maintenance of key ecological processes is likely far in excess of that expected based on their proportional extent (Lindenmayer \& Franklin, 2002; Schulte et al., 2006).

Apart from forest stands, the European landscape contains various types of non-forest woody vegetation, such as small landscape woodlots, adjacent linear woody vegetation along roads, streams, etc. (Auclair et al., 2000). Terminology related to woody vegetation features in the landscape is rather inconsistent (Forman \& Godron, 1986; Bulíŕ \& Škorpík, 1987; Ihse, 1995; Fjellstad \& Dramstad, 1999; Sklenička \& Lhota, 2002; Lindenmayer \& Franklin, 2002; Schulte et al., 2006; Rayburn \& Schulte, 2009; Kolařík et al., 2003; Součková, 2002; Sklenička et al., 2009; Skaloš \& Engstová, 2010; Plieninger et al., 2012a). In the Czech Republic, the term "permanent greenery" is used to describe forests, non-forest woody vegetation (scattered landscape woodlands and adjacent linear woodlands), as well as orchards, vineyards, hop fields, meadows, pastures, and sparse wood elements. Scattered woody vegetation refers to individual trees, bushes, or small woodlands in the open landscape, either on agricultural land or on non-agricultural land. In the Land Register of the Czech Republic, these landscape segments are not registered as forest or agricultural crops since they have different origins, ground disposition, spatial form and species composition (Kolařík et al., 2003). The Land Register of the Czech Republic is a public data set about the real estates in the Czech Republic, including their description and a list of geometric and positional determination ( $\breve{C} U Z K, 2013)$. Non-forest woody vegetation can be categorised according to location in the terrain, ground plan disposition, and priority function (Bulír \& Škorpík, 1987). According to the law (No. 289/1995 Coll.), a forest is a wood with its environment and land designated for fulfilling the forest's functions (the so-called PUPFL). In forestry, we can distinguish between a forest stand and a growth stand (Poleno \& Vacek, 2007).

Fjellstad \& Dramstad (1999) distinguished among coniferous, deciduous, and mixed woody growth in the landscape; Cousins \& Ihse (1998), in contrast, paid detailed attention to the different age groups of the forest. Ihse (1995) recorded only shrubs, linear segments such as roadsides, stonewalls, ditches or water runs, or individual trees; this work also distinguished among point objects, such as solitary wood plants and pad objects. Strand et al. (2002) pursued only the development of shrubby vegetation, while Clare \& Bunce (2006) focused on solitary wood plants. Oosterbaan \& Pels (2007) presented a detailed methodology for monitoring small landscape elements, including solitary trees and lines of trees, but this study focused only on an evaluation of the current state of forests and their functions, and did not attempt to analyse the historical development of those elements. Sklenička et al. (2009), in a recent analysis of changes in the medieval agricultural land around villages, focused on the development of linear woody vegetation structures. An interesting category is referred to as "farm trees", which are identical with “solitary trees” (Arnold \& Deewes, 1997; Van der Horst, 2006) or "trees outside forests" (FAO, 2001). This term has been defined by the FAO as "all trees not falling within the definition of non-forest woody growth and forest trees" (FAO, 2001). Nonforest woody growth can be subdivided into three categories: growth inside villages, scattered vegetation in the open landscape, and scattered roadside vegetation avenues (Skaloš \& Engstová, 2010). Vláčilová (2011) divided woody growth into forest wood elements-scattered and lined; to analyse the development of these growth areas, however, she used only the old medium-scale maps and military mapping 1, 2 and 3 . If they are further sub-categorized, the forests are divided only into coniferous, deciduous, and mixed.

Recently, several key studies have been devoted to monitoring forest or non-forest cover changes (Mathys et al., 2006; Kozak et al., 2008; Brandt et al., 2012; Plieninger et al., 2012a, b; Skaloš et al., 2012). However, certain deficits of methodological information on the historical development of forest and non-forest woods in the landscape are becoming evident. Namely, published works do not fully distinguish between forest and different categories of non-forest woody vegetation in the landscape (little landscape woodlands scattered in the landscape, adjacent linear woodlands along roads and streams), which is important for respecting the different dynamics and functional aspects of the mentioned different categories.

The main aim of the study lies in the methodological level. It aims to propose a relevant and common classification system for monitoring historic changes of all structural types of woody vegetation in the landscape. It should be also applicable to a variety of different source data, and for different localities characterised by differing landscape and forest types. This information is important for understanding the patterns, pressures, and forces that led to the formation of the present-day wood vegetation (Bürgi \& Schuler, 2003). The study may provide new theoretical and methodology bases for further practical disciplines, such as forestry, history, landscape planning, land consolidation process, etc. (Lannér, 2003; Jordan et al., 2005).

\section{Material and Methods}

\section{Study Area}

The study area was $57 \mathrm{~km}^{2}$ and included eight historical cadastres located in the Sokolov region in the west of the Czech Republic (Figure 1). This landscape has undergone significant and dynamic changes in the past 150 years mainly due to brown coal mining (Pecharová et al., 2011). However, there are also

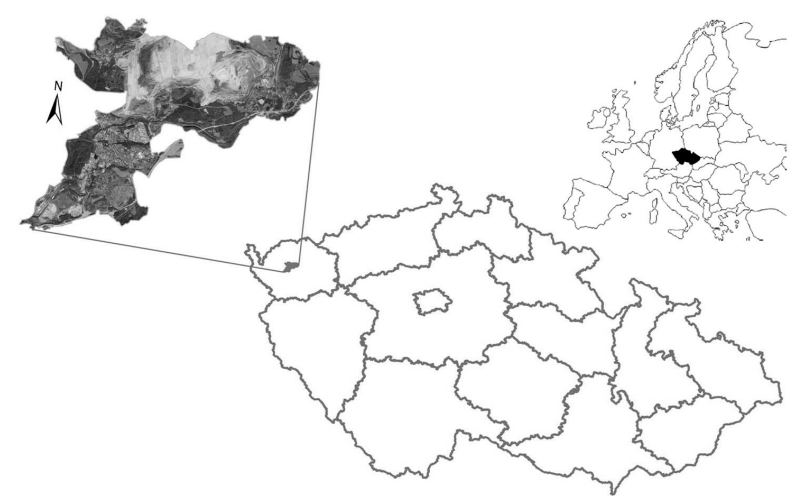

Figure 1.

Location of the area of interest in the Czech Republic (CENIA, 2011). 
other factors that have had a significant impact on the study area landscape change (urbanisation, road construction, land consolidation process, natural succession, forestry etc.). These have become a substantial criteria for the choice of the study area. The first mining records date back to the 17th century, before which it had been a fertile agricultural area (Prokop 1994). The Sokolov Basin forms part of the Krušné Hory range of the Czech massif, and lies in the southwestern wing of the sub-Krušné Hory rift valley. The development of the rift was accompanied by volcanic activity and by the emergence the large sub-Krušné Hory lake that no longer exists (Toušek et al., 2005); the large Sokolov Basin was created from tertiary vegetation growth that continues to be mined for coal today. The coal is used by many associated industries in this area (e.g. the Tisová power plant and the Vřesová pressure gasworks).

\section{Source Data}

Stable Cadastre Maps (1842)

Imperial prints of a stable cadastre (ČUZK, 2010) contain valuable historical information about the land use of the area, and also the important spatial properties of the landscape. These maps were provided with parcel numbers and drawn in the scale of 1:2880. Mapping work in the Czech Republic was carried out between 1826 and 1842. The maps recorded the original state of the landscape without additional drawing of later amendments (Semotánová, 2002; Trpáková et al., 2009). Scanned map layouts of the study area with a vertical and horizontal resolution of 300 dpi were purchased (ČÚZK, 2010).

\section{Aerial Photographs}

In the Czech Republic, as well as in many other countries (Ihse, 1995), a database of black and white historical aerial photographs from the 1930s onwards is available for landscape studies (Lipský, 2000; Lipský, 1995; Ihse, 1995; Fjellstad \& Dramstad, 1999; Plieninger, 2011, Bürgi \& Schuler, 2003). In the study, scanned and orthogonalised negatives from the growing season of 1953 were used (CENIA, 2010) giving information on the real woody vegetation structures in historic landscape.

\section{Present-Day Orthophotos}

To obtain information on the present-day state of woody vegetation in the study area landscape, orthophotos from 2011 were purchased. They were obtained through the aerial photography process, which was undertaken during the growing season (the same as for the aerial photos of 1953) of 2011 (CUZK, 2008) with resolution of $0.5 \mathrm{~m}$. The images were then photogrammetrically processed and transformed to the S-JTSK coordinate system. The average variation of the geodetically measured check points from the identical points on the orthophotomap was vy he0.36 m, vx i $0.33 \mathrm{~m}$. The identified lengths of the error vectors are not as large as a basic orthophoto pixel (Šíma, 2008).

\section{Processing the Data}

Imperial prints of stable cadastre areas and historic aerial photographs were acquired as digital data in raster form in high resolution, Stable Cadastre maps of $300 \mathrm{dpi}$, historic aerial photo of 900 dpi (ČÚZK, 2010; CENIA, 2010). This high resolution enabled the detailed interpretation and provided the possibility to produce high quality layouts. While historic aerial photos were obtained as georeferenced (CENIA, 2010), Stable Cadastre maps were processed using ArcGIS 9.3 (ESRI) and georectified in the S-JTSK_Krovak_East_North coordinate system using ground control points (objects or locations in the landscape where no spatial shift in the landscape is anticipated, e.g., churches, small religious architecture, road intersections); these points must be clear on both historic and present-day images. When errors occur in the transformation, the parameter used for estimating the accuracy of the transformation was RMS error (standard deviation). This adjustment was not necessary for the present-day orthophotos because IMS and WMS services allow georeferenced layers to be loaded. All base maps served only as a grid source for extracting data and for creating new vector layers.

\section{Interpretation of Old Maps, Aerial Photographs and Orthophotos}

The interpretation and vectorisation of the Stable Cadastre maps as well as aerial photographs and orthophotos were executed in the GIS environment according to a suggested classification system. The scale of the vectorisation was 1:2000. In the study, only polygons were distinguished using the polygonisation (vectorisation) process using the basic polygonisation functions available within the ArcGIS (ArcView 9.3) software. The woody vegetation polygons in the study area were polygonised based on the visual interpretation of old maps, aerial photos, and orthophotos. While it is rather simple to identify woody vegetation on old maps based on the use of the map legend, it is more difficult on the basis of the aerial photos and orthophotos. As far as the landscape feature was marked by treetops or shrub crowns, it was classified as wood vegetation (forest, scattered wood element, accompanying element of roads and water runs). To each woody vegetation feature, the attribute table was added. This attribute table consisted of the data on the wood elements classification type and the area in hectares. This provided an opportunity to quantitatively analyse time and spatial changes of the wood elements.

\section{Typology of Woody Vegetation}

This study focused on only woody vegetation in the landscape, which is a specific part of the previously defined term greenery. As different patches of woody vegetation are characterised by different dynamics, we distinguished between woody vegetation in the open landscape and woody vegetation in built-up areas. We classified woody vegetation into four categories based on the location, size, and shape of woody stand features captured from the various data sources (Table 1 ). However, the woody vegetation features consisted of patch, and also linear landscape structural features (Forman \& Godron, 1986).

In this study, a decision on whether the woody vegetation element was classified as linear or patch was made by subjective estimation and no shape or perimeter-to-edge ratio were calculated. However, basic landscape ecology criteria defining basic landscape structural elements were applied, e.g. linear landscape features referring to those elements whose length substantially exceeds the width (Forman \& Godron, 1986). Woodlands were classified as "settlement woodlands" in the event that the woody component followed directly on the built-up areas without interruption. Compact woodlands refer to those woody vegetation elements in the open landscape that are larger than 3 hectares, and are characterised by continuous forest cover. These woody elements mostly refer to the official forest land registered by the Land Registry, which is a functional category. However, the criteria applied here to differentiate woody vegetation resulted in 
Table 1.

Detailed description of categories in different woody stands.

\begin{tabular}{ll}
\hline Category & Description \\
\hline $\begin{array}{l}\text { Settlement } \\
\text { woodlands }\end{array}$ & $\begin{array}{l}\text { This category refers to woody stands located within the built-up areas. This refers to cities, towns, and villages, strip developments along } \\
\text { transport infrastructures, and areas occupied by shopping centres, industrial and commercial complexes. Settlement woodlands are usually } \\
\text { exposed to an intensive anthropogenic pressure as they are located within the built-up areas and fulfil many functions } \\
\text { (mainly aesthetic, nature conservation, and partly productive). }\end{array}$ \\
$\begin{array}{l}\text { Line adjacent } \\
\text { woodlands }\end{array}$ & $\begin{array}{l}\text { Line adjacent woodlands refer to linear landscape structural features in the landscape located along communication corridors } \\
\text { (pathways, roads, motorways, train tracks), along watercourses or along elements that are linear-shaped in an open landscape } \\
\text { (e.g. terraces). They provide mainly aesthetic and nature conservation functions. }\end{array}$ \\
$\begin{array}{l}\text { Landscape } \\
\text { woodlands }\end{array}$ & $\begin{array}{l}\text { This refers to patches of woody vegetation in the open landscape that are smaller than } 3 \text { hectares and typically surrounded } \\
\text { by agricultural land, or permanent grassland. These features can provide many different functions-primarily nature }\end{array}$ \\
conservation, aesthetic and productive timber areas. \\
$\begin{array}{l}\text { Compact } \\
\text { woodlands }\end{array}$ & $\begin{array}{l}\text { Continuous forest cover. These woody elements mostly refer to the official forest land registered by the Land Registry office, which is a } \\
\text { functional category. They are primarily for timber production, but also provide nature conservation and aesthetic services. }\end{array}$ \\
\hline
\end{tabular}

structural categories.

We classified woody vegetation into four following categories based on the location, size, and shape of features:

- Settlement woodlands,

- Line adjacent woodlands,

- Landscape woodlands,

- Compact woodlands.

\section{Observed Characteristics}

For the purposes of this study, characteristics of the landscape macrostructure were calculated (Lipský, 1995) using hectares and a percentage to quantify changes trajectories of the woody vegetation categories (area in hectares, proportion in percentages). With the help of changes in these characteristics over time, it was possible to execute an analysis of the development of woody growth, and conduct a spatial-temporal analysis in ArcGIS.

\section{Spatial Analysis of Woodland Development}

Old-growth ancient woodlands play an important role in nature conservation (Rayburn \& Schulte, 2009). Given that these areas stand for the features of the landscape memory (Skaloš \& Kašparová, 2012), they are valuable from the cultural heritage point of view as they bear information on the long-term relationships of our cultural landscape (Brandt et al., 2012). The analysis was performed in GIS, using the "intersection" function available in the ArcView 9.3 software. This analytical GIS tool allows the user to quantify and locate the temporal and spatial changes in the observed woodland patches resulting in quantifying and locating old-growth woodlands that have not changed over 50 years (between 1953 and 2011).

\section{Results}

\section{Development of Wood Elements}

Our results suggest that woody vegetation has changed considerably in the study region from 1842-2011 (Table 2, Figures 2-5). Specifically, in 1842 the most prevalent type in the area of interest was compact woodlands (1195 ha, 72.2\% of the total area of the woody vegetation in the study area), followed by line adjacent woodlands (232 ha, 14.0\%), landscape woodlands (208 ha, $12.6 \%$ ), and finally settlement woodlands (20 ha, $1.2 \%$ ) (Figure 2).

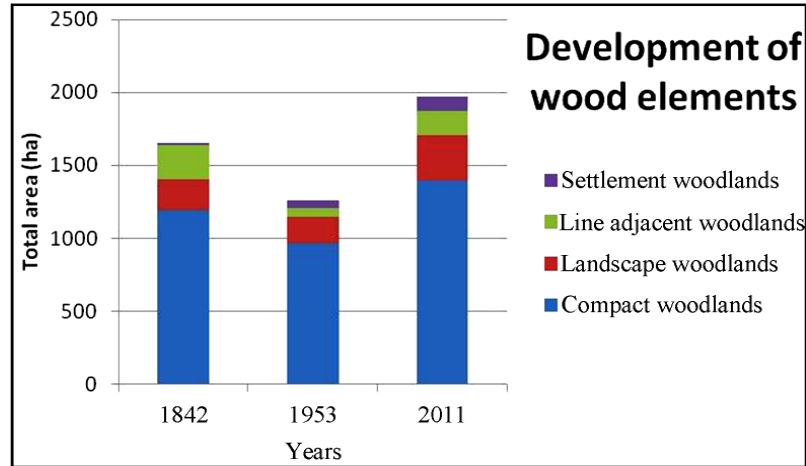

Figure 2.

Representation of individual woodlands categories.

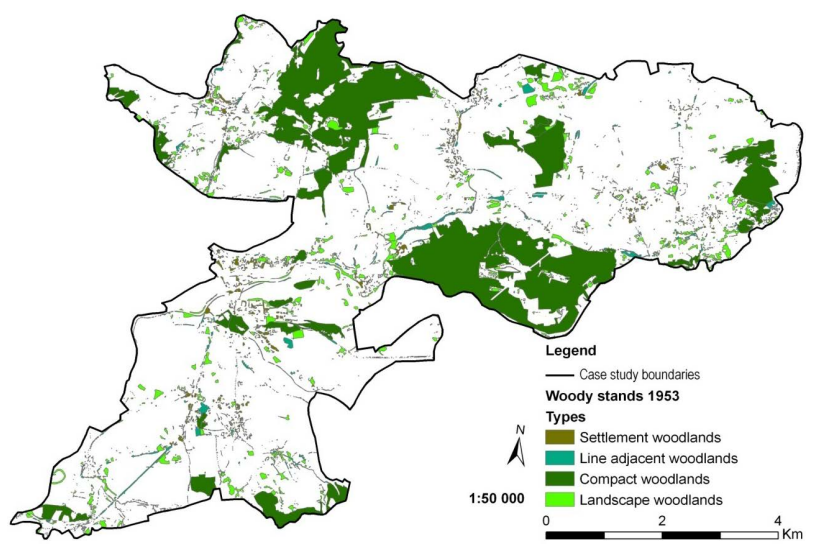

Figure 3.

Distribution of individual woodlands categories in 1953.

Until 1953 (Table 2), the most prevalent category was still compact woodlands, but this category dropped to 963.3 ha (76.4\% of the total area of the woody vegetation in the study area); this is a reduction in absolute area by 231.7 hectares. However, as the total area of woody vegetation decreased, the percentage of the compact woodlands increased up to $76.4 \%$. The second most prevalent category in 1953 was landscape woodlands (180.1 ha, $14.3 \%$ ). Here, too, there was a decrease in absolute area of 27.9 hectares, i.e. a decrease by $1.7 \%$, which was followed by line adjacent woodlands (67.3 hectares, 5.3\%). This category showed 
Table 2.

Changes in different types of wood elements.

\begin{tabular}{|c|c|c|c|c|c|c|}
\hline & \multicolumn{2}{|c|}{1842} & \multicolumn{2}{|c|}{1953} & \multicolumn{2}{|c|}{2011} \\
\hline & Area (ha) & $\%$ & Area (ha) & $\%$ & Area (ha) & $\%$ \\
\hline Line adjacent woodlands & 232 & 14 & 67.3 & 5.3 & 164 & 8.3 \\
\hline Compact woodlands & 1195 & 72.2 & 963.3 & 76.4 & 1398 & 70.8 \\
\hline Settlement woodlands & 20 & 1.2 & 49.8 & 4 & 104 & 5.3 \\
\hline Landscape woodlands & 208 & 12.6 & 180.1 & 14.3 & 309 & 15.6 \\
\hline
\end{tabular}

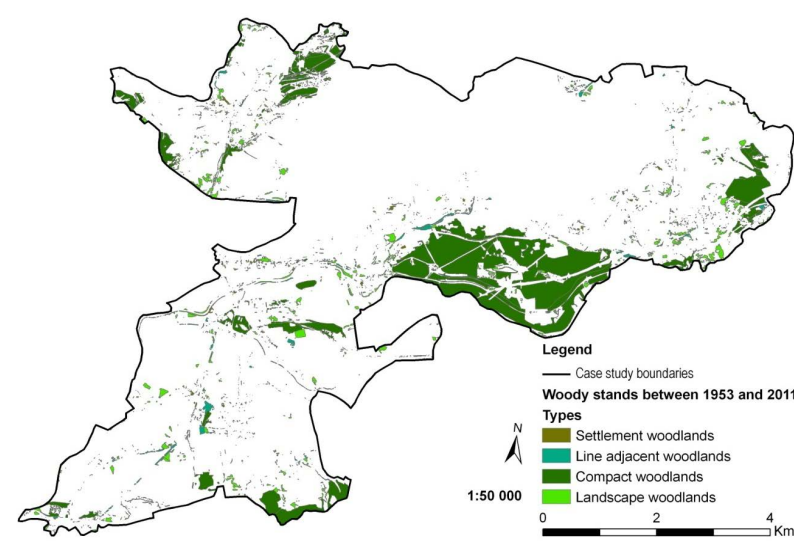

Figure 4.

Stability of the categories between 1953 and 2011.

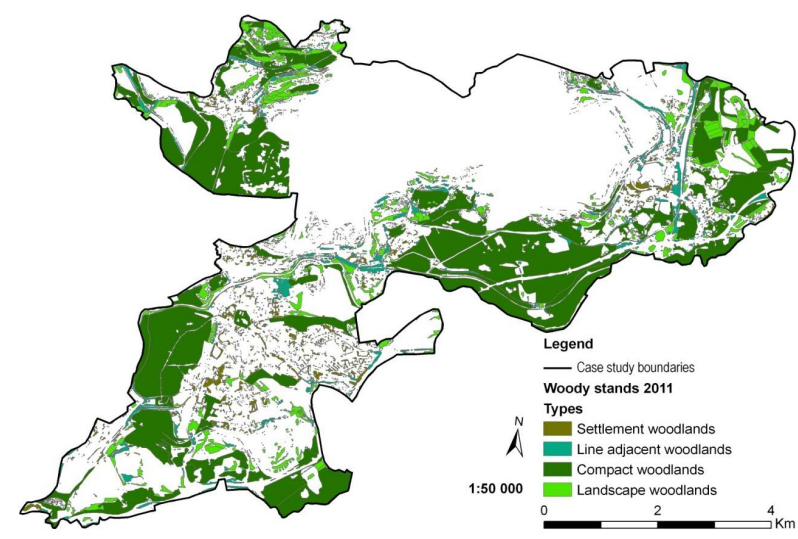

Figure 5.

Distribution of individual woodlands categories in 2011.

a steep decline in absolute area by 164.7 hectares (8.7\%). Settlement woodlands was the least represented category in 1953, with a total area of 49.8 hectares (4\%), and the same was true in the earlier previous period. Settlement woodlands were the only category to record a positive growth trend; the increase in total area was 29.8 hectares, or an increase of $2.7 \%$ (Figure 3).

In the most recent reporting period (2011), there was typically an increase in the absolute area of all categories of woody vegetation. The most prevalent category was again compact woodlands (1398.1 ha, an increase by 203.1 ha over the value for 1842 and an increase by 434.8 ha in comparison with 1953), and the second largest category was landscape woodlands (309.2 hectares, an increase by 101.2 hectares in comparison with 1842 and an increase by 129.0 ha in comparison with 1953). In 2011, line adjacent woodlands covered 164 ha, representing a decrease in area by 68.1 hectares in comparison with 1842, but an increase by 96.6 hectares in comparison with 1953. Settlement woodlands covered 103.6 hectares in 2011, which means an increase of 83.6 ha in comparison with 1842, and an increase by 53.9 ha in comparison with 1953 (Table 2, Figure 5).

\section{Stability of the Categories between 1953 and 2011.}

Between 1953 and 2011, 46.7\% of the compact woodlands remained unchanged, i.e. an area of 450 ha. The second most stable category was woodlands in the open landscape, in which there were no changes in an area of 17.8 hectares (9.9\%). Settlement woodlands remained unchanged on an area of 7.6 ha (15.2\%). The least stable category was line adjacent woodlands, which remained preserved between 1953 and 2011 over an area of only 4.2 hectares (6.3\%) (Figure 4).

\section{Discussion}

\section{Driving Forces behind Woody Vegetation Change}

Recently, much effort has been devoted to the analysis of the forest cover drivers (Bürg \& Schuler, 2003; Kozak et al., 2008; Baumann et al., 2012; Brandt et al., 2012; Plieninger et al., 2012a, b). This study has analysed the dynamics of the development of different woody vegetation elements over a time period of 165 years. During this period, the development of woody vegetation segments were influenced by environmental factors as well as by economic and social factors (Bičík \& Jeleček, 2001; Turner et al., 1996). In the landscape, there is a complex system that is structured not only by biological and biotic components, but also by a certain cultural layer and essence that plays a vital role in the relationship between the landscape and humans (Dneboská, 2006). When considering the formation of the landscape and woody vegetation structures of the study area presented in this paper, the political changes of the Czech Republic within the 165-year period under study should be taken into account. Also, the cultural context is to be taken into account when analysing landscape and woody vegetation historic changes (Lapka, 2008).

An important factor in the development of woody landscape segments in the area of interest is the worldwide phenomenon of urbanisation (Minghong et al., 2005; Arribas-Bel et al., 2011; Wang et al., 2012; Vermeiren et al., 2012; Míchal, 1994); by the 1960s, three-quarters of the inhabitants of the Czechoslovak Republic lived in towns (Blažek \& Kubálek, 2008). Other important factors were collectivisation (from 1951) resulting in connecting small land plots into large arable blocks (Lipský, 
1995; Jech, 2001). Second, the mining industry in the Sokolov area was expanded from the beginning of the 19th century (Skaloš \& Kašparová, 2012). Forty years of Socialist governments that aimed to intensify all categories of manufacture. Before 1953, there were approximately 1,404,000 small farms in the Czech Republic; after the first wave of socialist collectivisation, this number fell to 78,000. In 1989, when socialist rule came to an end, only 2000 small private farms remained in the Czech Republic (Hájek, 2008). Various approaches to farm management connected with activities such as land consolidation, ploughing the edges of fields, and field road networks were limiting factors that made the greatest contribution to the changes in the size and location of the accompanying line of wood elements and wood elements in the open landscape, which is clearly reflected in their stability between 1953 and 2011 (Skaloš \& Molnárová, 2012). The trend toward urbanisation, coupled with the extension of anthropogenic activities into the open landscape, e.g. mining and quarrying, road construction, commercial sub-urbanisation had a significant negative influence on the size and integrity of the compact woodlands (Keken et al., 2011; Anděl et al., 2005). Settlement woodlands remained unchanged between 1953 and 2011, with a total of 7.6 ha (15.2\%).

Another limiting factor during the monitored period that influenced the dynamics mainly of the compact woodlands was the forest management practise as well as the management of non-forest areas (areas of land that are not designated to perform forest functions, but on which compact woody vegetation grows). When analysing the significance of driving forces of an environmental-economic or social nature-it is necessary to take into account the conflict between reducing the intensity of land use and the abandonment of agricultural land, leading for example to landscape vegetation overgrowing trees, and, on the other hand, intensification of farming in the landscape, such as in the case of forestry (Šlezingr, 2003). This is a general view and takes into account regional differences. Interpreting the occurrence of woody vegetation in the landscape in 1842, it is important to bear in mind that Stable Cadastre maps show the landscape at the time of the beginning of the period of the Industrial Revolution (Lipský, 1995; Sýkora, 1998; Semotánová, 2002; Low \& Míchal, 2003). In this period, line adjacent woodlands covered the largest area (232 ha). Settlement and complex woodlands were spread fairly regularly in the landscape of 1842 due to the fact that surface coal mining had not affected the landscape by this year (Pecharová et al., 2011). The distribution of landscape woodlands and the line adjacent woodlands is primarily linked with a system of small fields with various methods of farming. Among other things, these elements fulfil the functions of highlighting land borders and eco-stabilisation (Sklenička, 2003; Löw \& Michal, 2003; Lipský, 2000).

Between 1842 and 1953, the effects of urbanisation on woody vegetation began to become evident. Urbanisation stands for the strongest driving forces in shaping the landscape of the 20th century, including woody vegetation (Minghong et al., 2005; Arribas-Bel et al., 2011; Wang et al., 2012; Vermeiren et al., 2012; Míchal, 1994). The occurrence of the categories analysed here may significantly document the socio-political aspects of the periods associated with the two world wars. Environmental problems were increasingly caused by unintended consequences that were difficult to predict, but did not reduce the taste of society for risk (Lapka, 2008). It has been shown that ploughing the fields and industrial exploitation were accompanied by destruction of the woody vegetation in the open landscape (Harmer et al., 2001).

Between 1953 and 2011, it was mostly mining activities in the northern part of the area of interest, together with urbanisation, that completely transformed the structure and functions of the landscape and woody vegetation of the studied landscape (Pecharová et al., 2011) There was also an association between urbanisation and the development of linear structures, which significantly fragmented the compact habitat (Liu et al., 2008; Noss, 1993; Hlaváč \& Anděl, 2001; Kušta et al., 2011). Roads have an obvious influence on the changes in ecosystems, especially on landscape structures (Liu et al., 2008). However, various compensatory measures have occurred to reduce the fragmentation and the barrier effect. With the growth of agglomerations of built-up areas, the sizes of settlement wood elements areas have grown as a substitute for natural spaces for the residents. The most recently observed period has produced a highly significant increase in wood elements across the landscape. This is primarily due to management aimed at stabilising the landscape that was damaged by mining, and secondly due to the process of natural succession (Uuttera et al., 1996; Koehler, 2000; Woziwoda \& Kopeć, 2012).

\section{Discussion on Methodology}

Recently, several papers dealing with methodology have focused on the analysis of forest or non-forest cover changes (Plieninger et al., 2012a; Pistorius et al., 2012; Achard \& Estreguil, 2003; Mathys et al., 2006; Vogt et al., 2007; Kozak et al., 2008, Skaloš \& Engstová, 2010; Lindberg \& Hollaus, 2012). However, the common typological system enabling the monitoring historic changes in woody vegetation is lacking. The classification system presented in this study is complex and suitable for wide use in various types of landscapes. The disadvantage is the subjectivity of determining the linear and patch woody vegetation elements and relatively high labour intensity. In the case of the analysis, the research subjects are different structural categories of woody vegetation in the landscape. Because the analysis is retrospective, it is necessary to consider the different nature of the materials that are used. This has to be integrated, which leads to the possibility of a range of inaccuracies. A key problem with the use of different types of graphic source data (historic maps, aerial photos) in landscape change research is the compatibility data on landscape attributes obtained from different sources, which differ in character, scale, quality, and resolution (Timár, 2004; Boltižiar et al., 2008; Skaloš et al., 2011; Plieninger et al., 2012b).

A particular problem, which is necessary to take into account, is the different nature of historical cadastral maps (cadastral maps stable from 1842) and aerial photographs. While cadastral maps provide information on the ownership structure of the landscape, aerial images contain information about the actual physical structure of the landscape (Skaloš \& Engstová, 2010). Data on the representation of linear and scattered woody vegetation on stable cadastre maps were distorted to some extent. The reason is that i.e. woody vegetation was only shown on some maps, and only in one area. Scattered vegetation was recorded only schematically. The solution to this problem may be to use the data correction and other documents, such as maps of the second Military mapping (Uhlírová, 2002).

\section{Management Links}

Pursuing the research on landscape changes and history, 
especially the relatively distant one, might seem a methodical or purely intellectual exercise. However, understanding the past is necessary for understanding the present and for right actions in the present (Bloch, 1952), and this is most apparent in case of changing landscapes.

Changing land use is held to be a crucial factor of global environment changes (Dale et al., 2000). The landscape change trajectories are often taken into account in conservation ecology when observing and predicting an influence of landscape changes on studied species. The woodlands being a highly important habitat type in landscape, fragmentation (Piquer-Rodriguez et al., 2012), connectivity (Theobald et al., 2011), habitat condition (Klenner et al., 2000) and other parameters are thoroughly studied as to their impact on selected species and their abundance.

Studying the historic changes in woodland condition can give a broader context to the development of management strategies. Knowledge of the native, old-growth forests functioning drawn from historic sources significantly helps with their restoration (Axelsson \& Ostlund, 2001). Since the woodlands are also an important source of fuel biomass, the better understanding of their structure changes are necessary to plan the management strategies concerning the responsible energy policy of the region (Fiorese \& Guariso, 2013), especially in the age of changing climate (Nitschke \& Innes, 2008). In the contrary the existing strategies can be evaluated and compared by model scenarios methods as to their impact on landscape and its ecological functions (Gustafson \& Crow, 1996), which can lead to reformulating of the management policy.

A detailed classification of woodland types is essential for determining the ecological and other environmental impacts of their changes. As Kadıogulları (2013) in the study on Turkey sub-temperate forest fragmentation states the increase of total forested area does not always lead to enhancement of landscape functionality.

These few examples of many show that studies on landscape and woodland changes can help to better understanding of their dynamic and thus better design of planning strategies. However, to put the acquired information into practical life means to build and keep the strong connections between the research and stakeholder spheres and to present the results in clear way (Dale et al., 2000).

\section{Conclusion}

The results of this study may further help to understand the long-term dynamics of the landscape change through learning the lessons of the history of the woody vegetation in the post-mining landscape in the north-western part of the Czech Republic. Here, the development of woody vegetation over the past 165 years has been very dynamic, and the extent to which each category was analysed fluctuated during certain periods, in direct relation with the political, social, economic or environmental development of the surveyed region. The results show that there has been an increasing trend since 1953 in the area of settlement woodlands. This can be explained as a way of offsetting the negative secondary effects of urbanisation that were rooted in industrial exploitation (brown coal mining) and that had a significant negative impact on the remaining categories of woody vegetation, mainly compact woodlands. The dynamics of the development of the line adjacent woodlands and landscape woodlands in all of the time periods studied here could docu- ment the different approaches mainly to agricultural management that the landscape has undergone.

The greatest contribution of the work lies in the methodological level. Although the proposed methodology should be seen as an essential step in the initial results of the extensive research project, the main advantage of the proposed methodology is that it enables users to trace back the history of woody vegetation in separate categories (forest and non-forest woody vegetation) respecting the different change dynamics of different woody stands in the landscape. Non-forest woody vegetation may be further subdivided based on the structural criteria into settlement, landscape, and adjacent linear woodlands. This information will help to understand historic changes in woody vegetation in the landscape. The typological system presented in this study is unique for its complexity and the possibility for wider use in various types of landscapes. Unfortunately, the method is flawed, as it consists of applying subjective criteria in differentiating linear and patch woody vegetation elements and no landscape metrics were calculated. Therefore, the application of landscape metrics to objectivise the woody vegetation classification forms the basis for future research aimed at the automation and objectification of the processes of woody vegetation elements classification. The disadvantage of the method is that it is time-consuming as well as labour-intense. For the purpose of the improvement and correction of historical data regarding the status and changes in woody vegetation, it will be necessary to use other types of source data (e.g. Military Survey Maps) and remote sensing methods.

The results of this retrospective study can be used predominantly in forest management practice, but also in other different forms of landscape planning practice, e.g. territorial planning, post-mining landscape reclamation, or regional development policies that will set future trends in the development of areas from the perspective of woody elements in the landscape. The key starting point is the understanding of the historical context and the driving forces involved in its development. Methodological conclusions of the study are useful in other fields, such as history, geography, etc.

\section{Acknowledgements}

The work reported on in this paper was supported by Ministry of Agriculture of the Czech Republic, project No. ČR QH 82106 Re-cultivation as a tool for landscape functionality regeneration after opencast brown coal mining. Special thanks belong to Robin Healey and Peter Kumble, Ph.D. for their kind English language corrections.

\section{REFERENCES}

Achard, F., \& Estreguil, Ch. (1995). Forest classification of Southeast Assia using NOAA AVHRR data. Remote Sensing of Environment, 54, 198-208. http://dx.doi.org/10.1016/0034-4257(95)00153-0

Arribas-Bel, D., Nijkamp, P., \& Scholten, H. (2011). Multidimensional urban sprawl in Europe: A self-organizing map approach. Computers, Environment and Urban Systems, 35, 263-275. http://dx.doi.org/10.1016/j.compenvurbsys.2010.10.002

Anděl, P., Gorčicová, I., Hlaváč, V., Miko, L., \& Andělová, H. (2005). Assessment of landscape fragmentation caused by traffic. Prague: AOPK.

Arnold, J. E. M., \& Deewes, P. A. (1997). Farms, trees, and farmers. Responses to agricultural intensification. London: Earthscan.

Auclair, D., Prinsley, R., \& Davis, S. (2000). Trees on farms in industrialised countries: Silvicultural, environmental and economics issues. 
Proceedings of IUFRO Meetings in 2000, Kuala Lumpur, August 2000. http://www.fao.org/docrep/004/y1997e/y1997e09.htm

Axelsson, A. L., \& Ostlund, L. (2001). Retrospective gap analysis in a Swedish boreal forest landscape using historical data. Forest Ecology and Management, 147, 109-122. http://dx.doi.org/10.1016/S0378-1127(00)00470-9

Beneš , J., Kaštovský, J., Kočárová, R., Kočár, P., Kubečková, K., \& Pokorný, P. (2002). Archaeobotany of the Old Prague Town defence system, Czech Republic: Archaeology, macro-remains, pollen, and diatoms. Vegetation History and Archaeobotany, 11, 107-120.

Berg, A., Ostlund, L., Moen, J., \& Olofsson, J. (2008). A century of logging and forestry in a reindeer herding area in northern Sweden. Forest Ecology and Management, 256, 1009-1020.

Bičík, I., \& Jeleček, L. (2001). Land use changes and their social driving forces in Czechia in the 19th and 20th centuries. Land Use Policy, 18, 65-73. http://dx.doi.org/10.1016/S0264-8377(00)00047-8

Blažek, P., \& Kubálek, M. (2008). Rural collectivization in Czechoslovakia 1948-1960 and central European consequences. Prague: Dokořán.

Bloch, M. (2009). Apologie pour l'histoire ou Métier d'historien. Paris: Armand Colin.

Bollschweiler, M., Stoffel, M., \& Schneuwly, D. M. (2008). Dynamics in debris-flow activity on a forested cone-A case study use any different dendroecological approaches. Catena, 72, 67-78.

http://dx.doi.org/10.1016/j.catena.2007.04.004

Boltiziar, M., Bruna, V., Chrastina, P., \& Krovakova, K. (2008). Dynamics potential of antique maps and aerial photographs for landscape changes assessment an example of the High Tatra Mts. Ekologia, 27, 65-81.

Brandt, J., Kuemmerle, T., Li, H., Ren, G., Zhu, G., \& Radeloff, V. (2012). Using Landsat imagery to map forest change in southwest China in response to the national logging ban ecotourism development. Remote Sensing of Environment, 121, 358-369. http://dx.doi.org/10.1016/j.rse.2012.02.010

Brůna, V., \& Křováková, K. (2006). Exploitation of old maps of medium and large scale for an investigation of forest development. Proceedings from Forests History and Development in the Czech Countries, Vol. 17, Srní, 18 October 2006, 111-117.

Buliřr, P., \& Škorpík, M. (1987). Scattered vegetation in the landscape. Prague: Průhonice.

Bürgi, M., \& Schuler, A. (2003). Driving forces of forest managementAn analysis of regeneration practices in the forest of the weiss Central Plateau during the 19th and 20th century. ForestEcology and Management, 176, 173-183.

Cenia (2011). Czech Environmental Information Agency. Aerial photos, 1953. Prague. http://kontaminace.cenia.cz

Cílová, Z., \& Woitsch, J. (2012). Potash-A key raw material of glass batch for bohemian glasses from 14th-17th centuries? Journal of Archaeological Science, 39, 371-380.

http://dx.doi.org/10.1016/j.jas.2011.09.023

Clare, T., \& Bunce, R. G. H. (2006). The potential for using trees to help define historic landscape zones: A case study in the English Lake District. Landscape and Urban Planning, 74, 34-45. http://dx.doi.org/10.1016/j.landurbplan.2003.09.009

Cousins, S. A. O., \& Ihse, M. (1998). A methodological study for biotope and landscape mapping based on CIR aerial photographs. Landscape and Urban Planning, 41, 183-192.

http://dx.doi.org/10.1016/S0169-2046(98)00057-7

ČÚZK (2009). Czech Office for Surveying, Mapping and Cadastre. Imperial prints of stable land. 1:2880, 1841. Praha. www.cuzk.cz

Dale, V. H., Brown, S., Haeuber, R. A., Hobbs, N. T., Huntly, N., Naiman, R. J., Riebsame, W. E., Turner, M. G., \& Valone, T. J. (2000). Ecological principles and guidelines for managing the use of land. Ecological Applications, 10, 639-670.

Dneboská, A. (2006). Searching one of the aspects of landscape identity. Protection of landscape-thirteen years of experience, successes and mistakes. Prague: CZU v Praze.

Ehsa, S., \& Chan, Y. (2000). Urban planning and development applications of gis. Reston, VA: American Society of Civil Engineers.
Geographic Information Systems Committee.

FAO (2001). Riddle, J. Food and Agriculture Organization of the United Nations. www.fao.org

Fiorese, G., \& Guariso, G. (2013). Modeling the role of forests in a regional carbon mitigation plan. Renewable Energy, 52, 175-182. http://dx.doi.org/10.1016/j.renene.2012.09.060

Fjellstad, W. J., \& Dramstad, W. E. (1999). Patterns of change in two contrasting Norwegian agricultural landscapes. Landscape and Urban Planing, 45, 177-191. http://dx.doi.org/10.1016/S0169-2046(99)00055-9

Gustafson, E. J., \& Crow, T. R. (1996). Simulating the effects of alternative forest management strategies on landscape structure. Journal of Environmental Management, 46, 77-94. http://dx.doi.org/10.1006/jema.1996.0008

Hájek, P. (2008). Is our country directly going ahead. Landscape of the Czech lands during the period 1948-1989 socialism. Prague: Malá Skála.

Harmer, R., Peterken, G., Kerr, G., \& Poulton, P. (2001). Vegetation changes during 100 years of development of two secondary woodlands on abandoned arable land. Biological Conservation, 101, 291304. http://dx.doi.org/10.1016/S0006-3207(01)00072-6

Hlaváć, V., \& Anděl, P. (2001). On the permeability of roads for wildlife: A handbook. Prague: AOPK.

Hultberg, T. (2008). Forest continuity and human impact-vegetation history of Torup forest, south-western Scania. Ph. D. Thesis, Alnarp: Swedish University of Agricultural Sciences.

Ihse, M. (1995). Swedish agricultural landscapes-Patterns and changes during the last 50 years, studied by aerial photos. Landscape and Urban Planning, 31, 21-37.

Jim, C. Y., \& Chen, W. Y. (2009). Diversity and distribution of landscape trees in the compact Asian city of Taipei. Applied Geography, 29, 577-587. http://dx.doi.org/10.1016/j.apgeog.2009.01.002

Jordan, G., van Rompaey, A., Szilassi, P., Csillag, G., Mannaerts, C., \& Woldai, T. (2005). Historical land use changes and their impact on sediment fluxes in the Balaton basin (Hungary). Agriculture, Ecosystems and Environment, 108, 119-133. http://dx.doi.org/10.1016/j.agee.2005.01.013

Kadiogullari, A. I. (2013). Assessing implications of land use and land cover changes in forest ecosystems of NE Turkey. Environmental Monitoring and Assessment, 185, 2095-2106. http://dx.doi.org/10.1007/s10661-012-2691-0

Keken, Z., Kušta, T., Ježek, M., \& Martiš, M. (2011). A comparison of changes in landscape structures in model sections of the D1 motorway. Journal of Landscape Studies, 4, 25-34.

Klenner, W., Kurz, W., \& Beukema, S. (2000). Habitat patterns in forested landscapes: Management practices and the uncertainty associated with natural disturbances. Computers and Electronics in Agriculture, 27, 243-262.

http://dx.doi.org/10.1016/S0168-1699(00)00110-1

Koehler, H. (2000). Natural regeneration and succession-Results from a 13 years study with reference to mesofauna and vegetation, and implications for management. Landscape and Urban Planning, 51, 123-130. http://dx.doi.org/10.1016/S0169-2046(00)00103-1

Kolařík, J. (2003). Care for trees growing outside forest.Vlašim: ČSOP.

Kozak, J., Estreguil, C., \& Ostapowicz, K. (2008). European forest cover mapping with high resolution satellite data: The Carpathians case study. International Journal of Applied Earth Observation and Geoinformation, 10, 44-55.

http://dx.doi.org/10.1016/j.jag.2007.04.003

Krása, J., \& David, V. (2006). Geographic information systems as a basis decision-making process, particularly for landscape engineering. Prague: CzechTechnical University in Prague.

Kušta, T., Ježek, M., \& Keken, Z. (2011). Mortality of large mammals on railway track. Scientia Agriculturae Bohemica, 42, 12-18.

Lannér, J. (2003). A long-term study of historical maps, tree densities, tree regeneration and grazing dynamics at Hallands Väderö. Ph.D. Thesis, Alnarp: Swedish University of Agricultural Sciences Department of Landscape Planning.

Lapka, M. (2008). Introduction to sociology of landscape. Prague: Karolinum. 
Lindberg, E., \& Hollaus, M. (2012). Comparison of methods for estimation of stem volume, stem number and basal area from airborne laser scanning data in hemi-boreal forest. Remote Sensing, 4, 10041023. http://dx.doi.org/10.3390/rs4041004

Lindenmayer, D. B., \& Franklin, J. F. (2002). Conserving forest biodiversity: A comprehensive, multiscaled approach. Washington, DC: Island Press.

Lipský, Z. (1998). Landscape ecology for students of geographic subjects. Prague: Karolinum.

Lipský, Z. (2000). Monitoring changes in the cultural landscape, the Institute of Applied Ecology. Kostelec nad Černými lesy: Czech University of Life Sciences.

Liu, S. L., Cui, B. S., Dong, S. K., Yang, Z. F., Yang, M., \& Holt, K. (2008). Evaluating the influence of road networks on landscape and regional ecological risk: A case study in Lancang River Valley of Southwest China. Ecological Engineering, 34, 91-99. http://dx.doi.org/10.1016/j.ecoleng.2008.07.006

Löw, J., \& Míchal, I. (2003). Landscape character. Kostelec nad Černými lesy: Lesnická práce.

Ložek, V. (2007). Zrcadlo minulosti. Česká a slovenská krajina v kvartéru. Praha: Dokořán.

Maděra, P., \& Zimová, E. (2005). Methodological design practices of local territorial system of ecological stability. Brno: Ústav Lesnické Botaniky, Typologie a Dendrologie LDF MZLU v Brně a Löw a Spol.

Manning, A., Fischer, J., \& Lindenmayer, D. (2006). Scattered trees are keystone structures. Implications for conservation. Biological Conservation, 132, 311-321. http://dx.doi.org/10.1016/j.biocon.2006.04.023

Mathys, L., Ginzler, C., Zimmermann, N. E., Brassel, P., \& Wildi, O. (2006). Sensitivity assessment on continuous landscape variables to classify a discrete forest area. Forest Ecology and Management, 229, 111-119. http://dx.doi.org/10.1016/j.foreco.2006.03.012

McCollin, D. (2000). Hedgerow policy and protection-Changing paradigms and the conservation ethic. Journal of Environmental Management, 60, 3-6. http://dx.doi.org/10.1006/jema.2000.0357

Míchal, I. (1994). Ecological stability. Brno: Veronica.

Tan, M. H., Li, X. B., Xie, H., \& Lu, C. H. (2005). Urban land expansion and arable land loss in China-A case study of Beijing-Tianjin-Hebei region. Land Use Policy, 22, 187-196.

Nair, P. K. R., Kumar, B. M., \& Nair, V. D. (2009). Agroforestry as a strategy for carbon sequestration. Journal of Plant Nutrition and Soil Science, 172, 10-23. http://dx.doi.org/10.1002/jpln.200800030

Nitschke, C. R., \& Innes, J. L. (2008). Integrating climate change into forest management in South-Central British Columbia: An assessment of landscape vulnerability and development of a climate-smart framework. Forest Ecology and Management, 256, 313-327. http://dx.doi.org/10.1016/j.foreco.2008.04.026

Noss, R. F. (1993). Wildlife corridors. In D. S. Smith, \& P. C. Hellmund (Eds.), Ecology of greenways (pp. 43-98). Minneapolis, MN: University of Minneapolis Press.

Ohlson, M., \& Tryterud, E. (1999). Long-term spruce forest continuity -A challenge for a sustainable Scandinavian forestry. Forest Ecology and Management, 124, 27-34.

Oosterbaan, A., \& Pels, M. (2007). Monitoring of small landscape elements in The Netherlands. Landscape Research, 32, 95-102. http://dx.doi.org/10.1080/01426390601097792

Pattanayak, S., \& Mercer, E. (1997). Valuing soil conservation benefits of agroforestry. American Journal of Agricultural Economics, 79, 1714.

Pecharová, E., Svoboda, I., \& Vrbová, M. (2011). Obnova jezerní krajiny pod Krušnými horami. Kostelec nad Černými lesy: Lesnická práce.

Piquer-Rodriguez, M., Kuemmerle, T., Alcaraz-Segura, D., Zurita-Milla, R., \& Cabello, J. (2012). Future land use effects on the connectivity of protected area networks in southeastern Spain. Journal for Nature Conservation, 20, 326-336. http://dx.doi.org/10.1016/j.jnc.2012.07.001

Pistorius, T., Schaich, T., Winkel, G., Plieninger, T., Bieling, C., Konold, W., \& Volz, K. R. (2012). Lesson for REDDplus: A comparative analysis of the German discourse on forest function and the global ecosystem service debate. Forest Policy and Economics, 18,
4-12. http://dx.doi.org/10.1016/j.forpol.2011.09.001

Plieninger, T. (2011). Capitalizing on the carbon sequestration potential of agroforestry in Germany's agricultural landscapes: Realigning the climate-change mitigation and landscape conservation agendas. Landscape Research, 36, 435-454. http://dx.doi.org/10.1080/01426397.2011.582943

Plieninger, T., Schaich, H., \& Kizos, T. (2011). Land-use legacies in the forest structure of silvopastoral oak woodlands in the Eastern Mediterranean. Regional Environmental Change, 11, 603-615. http://dx.doi.org/10.1007/s10113-010-0192-7

Plieninger, T., Schleyer, C., Mantel, M., \& Hostert, P. (2012a). Is there forest transition outside forests? Trajectories of farm trees and effects on ecosystem services in an agricultural landscape in Eastern Germany. Land Use Policy, 29, 233-243. http://dx.doi.org/10.1016/j.landusepol.2011.06.011

Plieninger, T., Ferranto, S., Huntsinger, L., Kelly, M., \& Getz, C. (2012b). Appreciation, use, and management of biodiversity and ecosystem services in California's working landscapes. Environmental Management, 50, 427-440. http://dx.doi.org/10.1007/s00267-012-9900-z

Poleno, Z., \& Vacek, S. (2007). Cultivation of forests II. Theoretical background of Forest Cultivation. Kostelec nad Černými lesy: Lesnická práce.

Prokop, V. (1994). Chapters from the history of Sokolov. Sokolov: Sokolov District Museum.

Rapant, P. (2002). Introduction to geographic information systems. Ostrava: VŠB-TU.

Rayburn, A. P., \& Schulte, L. A. (2009). Landscape change in an agricultural watershed in the U.S. Midwest. Landscape and Urban Planning, 93, 132-141. http://dx.doi.org/10.1016/j.landurbplan.2009.06.014

Romportl, D., \& Chuman T. (2010). Changes in landscape structure due to residential and commercial suburbanization in the Czech Republic. www.Suburbanizace.cz

Ryszkowski, L., \& Kedziora, A. (2007). Modification of water flows and nitrogen fluxes by shelterbelts. Ecological Engineering, 29, 388400. http://dx.doi.org/10.1016/j.ecoleng.2006.09.023

Sádlo, J. (2005). Krajina a revoluce. Prague: Malá Skála.

Salačová, A. (2009). Current issues of protection landscape: Chosen landscape character assessment problems from the land use planning point of view (1st ed.). Prague: CZU.

Schulte, L. A., Liebman, M., Asbjornsen, H., \& Crow, T. F. (2006). Agroecosystem restoration through strategic integration of perennials. Journal of Soil and Water Conservation, 61, 164-169.

Shvidenko, A., Barber, C. V., \& Persson, R. (2005). Forest and woodland systems. Proceedings from Ecosystems and Human Well-being: Current State and Trends. Washington, DC: Island Press, 585-621.

Skaloš, J., \& Engstová, B. (2010). Methodology for mapping non-forest wood elements using historic cadastral maps and aerial photographs as a basis for management. Journal of Environmental Management, 91, 831-843. http://dx.doi.org/10.1016/j.jenvman.2009.10.013

Sklenička P., Molárová, K., Brabec E., Kumble P., Pittnerová, B., Pixová, K., \& Šálek, M. (2009). Remnants of medieval field patterns in the Czech Republic: Analysis of driving forces behind their disappearance with special attention to the role of hedgerows. Agriculture, Ecosystems and Environment, 129, 465-473. http://dx.doi.org/10.1016/j.agee.2008.10.026

Sklenička, P. (2003). Basics of landscape planning. Prague: Nakladatelství Naděžda Skleničková.

Součková, H. (2002). The economics of the scattered green restoration in cultural landscape. Agricultural Economics Journal, Prague: Research Institute of Agricultural Economics.

Strand, G. H., Dramstad, W., \& Engan, G. (2002). The effect of field experience on the accuracy of identifying land cover types in aerial photographs. International Journal of Applied Earth Observation and Geoinformation, 4, 137-146. http://dx.doi.org/10.1016/S0303-2434(02)00011-9

Svoboda, P. (1952). Life of forest. Prague: SZN.

Sýkora, J. (1998). Territorial planning—Part 1 Historical development of the Czech countryside. Prague: Czech Technical University in Prague. 
Šlezingr, M. (2003). Applied and landscape ecology. Brno: Akademické nakladatelství CERM.

Theobald, D. M., Crooks, K. R., \& Norman, J. B. (2011). Assessing effects of land use on landscape connectivity: Loss and fragmentation of western U.S. forests. Ecological Applications, 21, 2445-2458. http://dx.doi.org/10.1890/10-1701.1

Timzingr, M. (2003). Applied and landscape ecology. Brno: Akademické nakladatelství CERM.

Toušek, V. (2005). Portraits of the regions. Ministry for Regional Development, Prague: MMR ČR.

Trpáková, I., (2009). Reconstruction of historical land use of the Sokolov region: Landscape in the mirror of stable cadastral maps. Kostelec nad Černými lesy: Lesnická práce.

Turner, N. G., \& Wear, D. N. (1996). Land ownershipand land-cover ganges in Southern Appalachian Highlands and the Olympic Peninsula. Ecological Applications, 6, 1150-1172. http://dx.doi.org/10.2307/2269599

Uhliřová, L. (2002). Současný stav využití starých map pro sledování krajinných změn. Krajina 2002, od poznání k integraci, sborní k z konference, Ústí nad Labem.

Van der Horst, D. (2006). A prototype method to map the potential visual-amenity benefits of new farm woodlands. Environment and Planning B: Planning and Design, 33, 221-238.

http://dx.doi.org/10.1068/b31172

Uuttera, J., Maltamo, M., \& Kuusela, K. (1996). Impact of forest management history on the state of forests in relation to natural forest succession comparative study, North Karelia, Finland vs. Republic of Karelia, Russian Federation. Forest Ecology and Management, 83, 71-85. http://dx.doi.org/10.1016/0378-1127(95)03698-9
Vaněčková, T. (2011). Using old military survey maps to monitor changes in the development of forest and non-forest wood vegetation in the Sokolov Region. Diploma Thesis, Prague: Czech University of Life Scicences.

Verchot, L. V., Van Noordwijk, M., Kandji, S., Tomich, T., Ong, C., Albrecht, A., Mackensen, J., Bantilan, C., Anupama, K. V., \& Palm, C. (2007). Climate change: Linking adaptation and mitigation through agroforestry. Mitigation and Adaptation Strategies for Global Change, 12, 901-918. http://dx.doi.org/10.1007/s11027-007-9105-6

Vermeiren, K., Van Rompaey, A., Loopmans, M., Serwajja, E., \& Mukwaya, P. (2012). Urban growth of Kampala, Uganda: Pattern analysis and scenario development. Landscape and Urban Planning, 106, 199-206. http://dx.doi.org/10.1016/j.landurbplan.2012.03.006

Vláčilová, V. (2011). The use of old military maps for monitoring changes in the development of forest and woody vegetation outside the forest in Sokolov. Diploma Thesis, Prague: Czech University of Life Sciences in Prague.

Vogt, P., Riitters, K. H., Iwanowski, M., Estreguil, C., Kozak, J., \& Soille, P. (2007). Mapping landscape corridors. Ecological Indicators, 7, 481-488. http://dx.doi.org/10.1016/j.ecolind.2006.11.001

Wang, L., Li, C., C., Ying, Q., Cheng, X., Wang, X.,Y., Li, X.,Y., Hu, L.,Y., Liang, L., Yu, L., Huang, H. B., \& Gong, P. (2012). China's urban expansion from 1990 to 2010 determined with satellite remote sensing. Chinese Science Bulletin, 57, 2802-2812. http://dx.doi.org/10.1007/s11434-012-5235-7

Woziwoda, B., \& Kopeć, D. (2012). Afforestation or natural succession? Looking for the best way to manage abandoned cut-over peatlands for biodiversity conservation. Ecological Engineering, Available online 26 January 2013. 